\title{
Overcapacity as a Barrier to Renewable Energy Deployment: The Spanish Case
}

\author{
Pablo del Río ${ }^{1}$ and Luis Janeiro ${ }^{2}$ \\ ${ }^{1}$ Consejo Superior de Investigaciones Científicas, C/Albasanz 26-28, 28037 Madrid, Spain \\ ${ }^{2}$ Ecofys, Kanaalweg 15-G, 3526 KL Utrecht, Netherlands \\ Correspondence should be addressed to Pablo del Río; pablo.delrio@csic.es
}

Received 29 March 2016; Revised 17 May 2016; Accepted 25 May 2016

Academic Editor: Umberto Desideri

Copyright (C) 2016 P. del Río and L. Janeiro. This is an open access article distributed under the Creative Commons Attribution License, which permits unrestricted use, distribution, and reproduction in any medium, provided the original work is properly cited.

Renewable energy sources (RES) play a critical role in the low-carbon energy transition. Although there is quite an abundant literature on the barriers to RES, the analysis of the electricity generation overcapacity as a barrier to further RES penetration has received scant attention. This paper tries to cover this gap. Its aim is to analyse the causes and consequences of overcapacity, with a special focus on the impact on RES deployment, using Spain as a case study. It also analyses the policies which may mitigate this problem in both the short and the longer terms.

\section{Introduction}

Climate change mitigation is arguably one of the greatest challenges facing humankind. Drastic emissions reductions will be required in order to put the world economy on emissions concentration path which minimizes the risk of collapse of the climate system. Generally, a 1.5- to 2-degree temperature increase above preindustrial levels is deemed compatible with this goal. In turn, this involves emissions concentration level of between 400 and 450 parts per million of $\mathrm{CO}_{2}$ equivalent. Stabilizing concentrations at these concentration levels will require that global net emissions peak in the very short term, decline rapidly after that time, and reach zero soon after 2050 . There is a wide consensus that the emissions reductions being required are substantial and that attaining such drastic reductions will require a mix of technologies. For example, the International Energy Agency [1] shows that, in order to put the world economy on an emissions path which is compatible with 2 degrees, emissions would have to be reduced by $40 \mathrm{GtCO}_{2}$ in 2050 with respect to a business-as-usual scenario. This reduction would be achieved in the least-cost manner through a combination of technologies, including renewables (34\% of the required reduction), energy efficiency (33\%), and carbon capture and storage (14\%).
Renewable energy sources (RES) play a critical role in the low-carbon energy transition or energy revolution. There is quite an abundant literature on the relevance of RES in this energy transition as well as on the barriers to RES (see [2] for a review). However, to the best of our knowledge, the existence of electricity generation overcapacity as a barrier to further RES penetration has not been addressed in the literature so far. This paper tries to cover this gap. Its aim is to analyse the causes and consequences of overcapacity, with a special focus on the impact on RES deployment, using Spain as a case study. It also analyses the policies which may mitigate this problem in both the short and the longer terms. The focus on Spain is justified because this country has had both a substantial RES penetration in the past and a problem of overcapacity in its electricity generation sector. However, it is not the only country with this problem in the EU (see Section 2).

We rely on several sources of information. First, in order to identify the extent of the problem, official data on the electricity generation capacity and electricity demand have been used. Second, a deep literature review on the causes and consequences of this problem, relying on the views of a wide array of stakeholders, has been performed. Finally, a draft text was produced with the above-mentioned sources. It was sent to several stakeholders and their feedback and views were incorporated in the text. 
Accordingly, this paper is structured as follows. The next section discusses the degree of the problem, that is, how much overcapacity exists in the Spanish electricity system. Section 3 is dedicated to the analysis of the causes, whereas Section 4 discusses the main consequences of overcapacity. Section 5 considers several policy options to address this problem. Section 6 provides the results of our interviews on the views of stakeholders. Section 7 concludes.

\section{How Much Overcapacity Is There in the Electricity System?}

Starting in the mid-90s, Spain was one of the first EU Member States to adopt effective support schemes for renewable energy in the power sector. By the time the current $\mathrm{EU}$ renewable energy directive (2009/28/EC) was adopted, Spain had already deployed more than $16 \mathrm{GW}$ of wind power and more than $3 \mathrm{GW}$ of solar photovoltaics, being one of the EU countries with a higher degree of penetration of renewables in its power system.

In 2010, Spain started a period of several profound energy policy changes in the direction of reducing support for RES. In January 2012, the Spanish Government decided to stop registration of new RES installations (Real Decretoley 1/2012, January 27th, 2012). In 2013, the Energy Reform was announced, introducing a completely new retribution scheme for RES, which included retroactive cuts in economic support for already existing installations (Real Decreto 413/2014, June 6th, 2014). These policy changes have resulted in a de facto halt of RES deployment in the country.

The main argument used to justify these decisions has been the need to contain the increasing costs of support for RES in order to correct the "tariff deficit" affecting the Spanish power system. (The tariff deficit refers to revenues (electricity prices) not covering regulated costs over the period. This tariff deficit reached 30000 million $€$ in 2013, about 3\% of Spain's GDP.) However, an often less mentioned contributing factor for this change in policy may be the fact that the Spanish power system suffers from a serious excess of generation capacity.

The electricity generation capacity installed in the last 15 years has increased significantly and virtually doubled between 2001 and 2014, from $55 \mathrm{GW}$ in 2001 to $102 \mathrm{GW}$ in 2014. Most new generation capacity came mainly from two technologies: wind power and natural gas-fuelled combined cycle gas turbines (CCGTs). Between 2003 and 2010, Spain installed $25.3 \mathrm{GW}$ of natural gas-fuelled generation plants. From 2010 to 2014, the CCGT capacity has remained roughly constant. Over the same period 2003-2014, installed wind power increased from $6.2 \mathrm{GW}$ to $22.8 \mathrm{GW}$. Figure 1 shows the evolution of the installed capacity per technology.

However, what seems more relevant is comparing the evolution of the installed capacity with the maximum electricity demand, which provides an indicator of the security of supply which the system has to safeguard.

Figure 2 shows the evolution of the installed generation capacity compared to the evolution of the hourly peak demand in the country (in the peninsular system). As it can

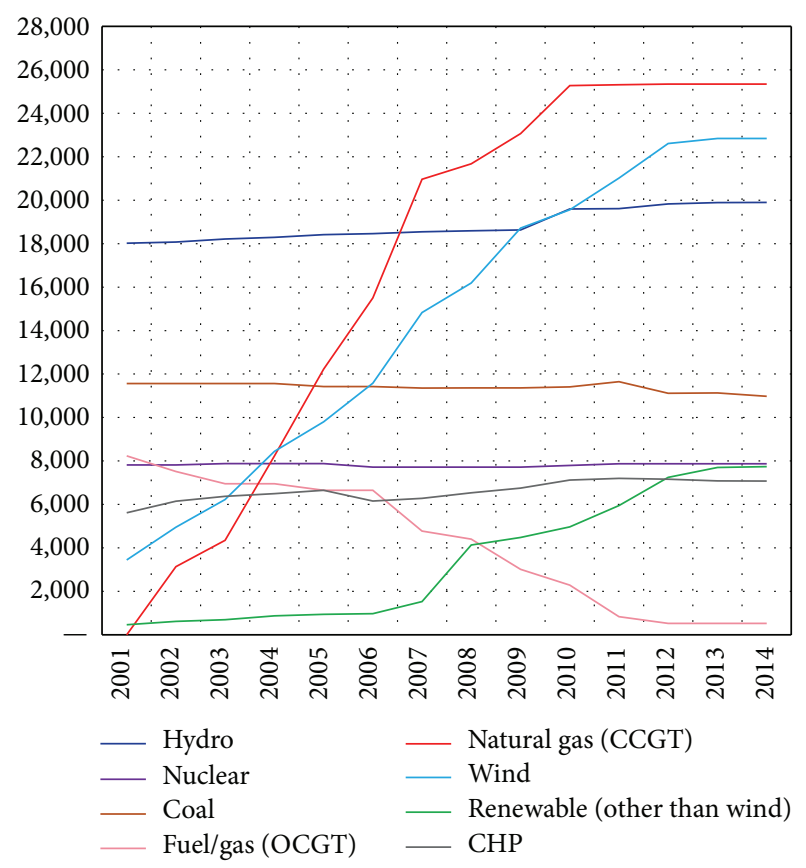

FIGURE 1: Evolution of the installed capacity (in MW) per technology. Source: our own elaboration from REE data.

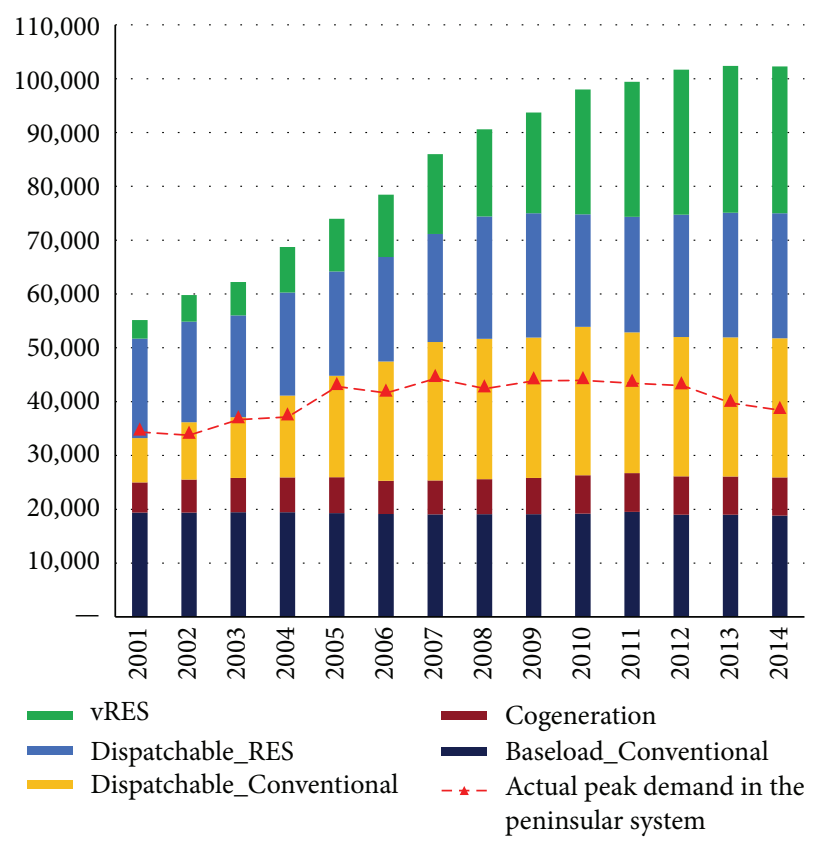

FIGURe 2: Peak power demand versus available capacity (MW). Source: our own elaboration. Data source: REE.

be seen from the graph, and in contrast to what happened in the last half of the 90s, the gap between the two has been steadily growing in the last 10 years. More importantly, the excess dispatchable capacity has also increased significantly over the same period.

Back in 2001, peak demand was roughly the same as the sum of all conventional installed capacities (including 
TABLE 1: Installed power capacity and maximum peak power demand coverage.

\begin{tabular}{lcc}
\hline & $\begin{array}{c}\text { Installed power capacity as of 31 } \\
\text { December 2013 (102 GW) }\end{array}$ & $\begin{array}{c}\text { Coverage of maximum peak } \\
\text { power demand 38.7 GW in 2014 }\end{array}$ \\
\hline Combined cycle & 24.8 & $7 \%$ \\
Coal & 10.7 & $2.5 \%$ \\
Nuclear & 7.7 & $18.9 \%$ \\
Fuel/gas & 0.5 & $0 \%$ \\
Cogeneration and others & 7 & $10.8 \%$ \\
Hydro & 19.5 & $24 \%$ \\
Wind & 22.3 & $34.5 \%$ \\
Solar PV & 4.3 & $0.1 \%$ \\
Solar thermoelectric & 2.2 & $0.1 \%$ \\
Renewable thermal & 1 & $1.5 \%$ \\
Importer balance regarding international exchanges & - & $0.6 \%$ \\
\hline
\end{tabular}

Source: Red Eléctrica de España [3].

${ }^{*}$ Pumped storage not included.

nuclear, coal, gas, and cogeneration plants). The $18 \mathrm{GW}$ of dispatchable RES capacity available (mostly hydro) provided a "safety buffer" to guarantee security of supply. Additionally, there was an incipient, but already growing, amount of variable RES (vRES) in the system.

In 2014, the situation was radically different. Conventional capacity alone was already $13 \mathrm{GW}$ larger than peak demand, which remained roughly at 2001 levels. Additionally, there are $23 \mathrm{GW}$ of dispatchable RES capacity and $27 \mathrm{GW}$ of variable RES capacity in the system. The installed capacity of RES in 2014 was even much higher than the historical peak demand, which occurred in 2007.

The most recent data show that installed power capacity more than doubles maximum peak demand in the day with the maximum electricity demand in the Spanish system (4 February 2014, between 8 p.m. and 9 p.m.); for example, compare columns 2 and 3 in Table 1.

Notwithstanding, the Spanish overcapacity problem has to be put in European context. Overcapacity problems are present or have been present in other EU countries. According to the "Leistungsbilanz" report [4], the day with the maximum load in Germany was December 5th 2013. On that day, the "secured capacity" was $116.3 \mathrm{GW}$ and the maximum load was $79.1 \mathrm{GW}$. Therefore, there was a security margin $37.3 \mathrm{GW}(47 \%)$.

However, the Spanish system has a larger excess capacity than other EU countries. Following the methodology of the European Network of Transmission System Operators for Electricity (ENTSO-E), the Spanish Ministry of Industry [5] determined that the "demand coverage ratio" of the Spanish system (1.73) was much higher than Italy (1.28), Germany (1.21), the UK (1.15), or France (1.09) (this study analysed values for the year 2011).

\section{What Are the Factors Behind Overcapacity?}

At a very general level, the causes of overcapacity are related to the factors affecting both sides of the problem, the supply, and the demand side, that is, factors influencing the substantial increase in capacity and other factors behind the stagnant evolution of electricity demand. We have identified a number of contributing causes, some of them interrelated to some extent, which we describe below.

3.1. Risks of Blackouts in the Late 1990s. A major risk in a context of highly increasing electricity demand (see below) is that this demand outpaces the installed generation capacity, leading to blackouts.

In the second half of the 90s, the gap between the "firm" generation capacity available (baseload and dispatchable plants) in the Spanish system and the peak hourly demand was closing at a very fast pace. Installed power in the "ordinary regime" (baseload plus dispatchable) was about 25000 MW in 1996, increasing to about 34000 MW in 2000. Peak hourly demand remained more or less flat in the same period at between 43000 and $45000 \mathrm{MW}$ [6]. This resulted in some situations of high risks of blackouts in some regions of the country.

Indeed, in the early 2000s, several cuts in electricity supply occurred in Spain, which led governments to "urgently" approve a considerable number of CCGT projects [7]. The risk of a blackout was especially critical in regions located in the Mediterranean coast (Cataluña, Comunidad Valenciana, and Murcia) [8].

\subsection{Planning: Wrong Projections of Electricity Demand.} The aforementioned risk of blackouts led to a government response to increase the generation capacity (see below). Infrastructure planning is done years in advance and at that point demand was growing very quickly. Estimations of required new generation capacity were based on wrong projections of electricity demand, possibly influenced by the economic prosperity at the time, but apparently ignoring that economic ups and downs, in short cycles, are a main feature of virtually all economies. Indeed, the increasing and decreasing sides of the economic cycle are usually both more pronounced in Spain compared to the rest of EU countries. 


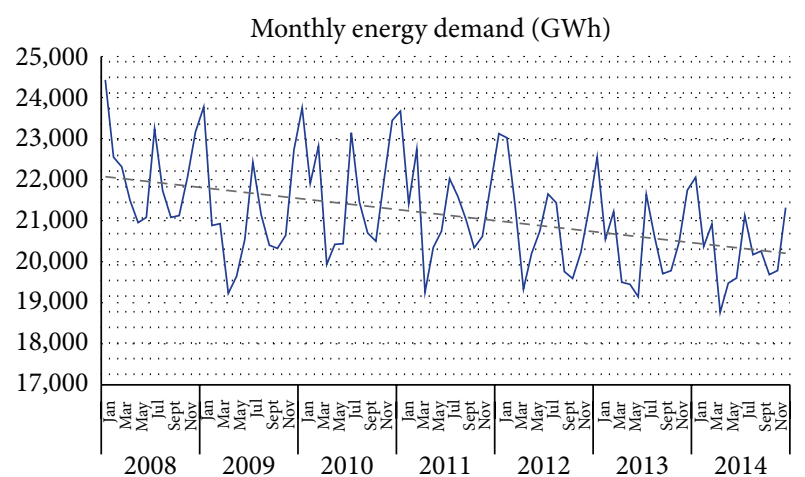

FIGURE 3: Monthly electricity demand 2008-2014. Source: REE [9] and REE [10].

In contrast to the developments in installed capacity, the power demand forecasts done in the early 2000s turned out to be too optimistic. The 2005 revision of the Spanish Plan for Power and Gas Infrastructure 2002-2011 estimated that peak power demand would grow $24 \%$ in 6 years (from $43 \mathrm{GW}$ in 2005 to $53 \mathrm{GW}$ by 2011) (Plan Infraestructuras Eléctricas y Gasistas 2002-2011 (review of 2005)). These estimations, however, did not materialise in practice. The Spanish economy started to decelerate in 2007 and, after the global financial crisis in 2008, Spain entered a period of economic stagnation/recession. Actual peak power demand in 2011 was $44 \mathrm{GW}$ (17.5\% below estimations). Since 2011, the peak power demand has further decreased to $39 \mathrm{GW}$ in 2014 , a number comparable to the maximums reached a decade earlier.

According to the Ministry of Industry [5] itself, forecasts on the growth of GDP and electricity deviated considerably from the actual trends. GDP and electricity demand were forecasted to increase by an accumulated $25 \%$ and $24 \%$, respectively, in 2013 compared to 2005 levels. In contrast, GDP grew by only $2 \%$ and electricity demand was reduced by $1 \%$ in such period. Figure 3 shows the evolution of the monthly electricity demand from 2008 to 2014.

3.3. Government Investment Signals. Planning errors were not only restricted to the estimations of power demand. There was also a lack of appropriate coordination/monitoring of long-term power system requirements between renewable deployment objectives and developments in the conventional generation sector.

Through regulations or the approval of planning documents, the government undeniably influenced the expectations of investors in particular technologies. In particular, this was the case with the two technological categories undergoing the greatest growth rates in the 2000s. The general idea was to force an energy transition towards less polluting fuels and more efficient plants and away from coal and fuel-oil plants, that is, CCGTs and RES.

3.3.1. Investment in CCGTs. The incentives driving investment in these two technologies (RES and CCGTs) were, however, very different. Investment in new conventional
TABLE 2: Objectives for RES-E in the two renewable energy plans (1999 and 2005).

\begin{tabular}{lcc}
\hline & \multicolumn{2}{c}{ Objectives for 2010 } \\
& PFER (1999) & PER (2005) \\
\hline Small hydro (<10 MW) & 2230 & 13521 \\
Hydro (between 10 MW and 50 MW) & 3151 & 3257 \\
Large hydro (>50 MW) & 13420 & 2199 \\
Wind & 8974 & 20155 \\
Biomass & 1897 & 1317 \\
Cocombustion (biomass) & 78 & 722 \\
Biogas & 144 & 235 \\
Solar PV & 200 & 400 \\
Solar thermoelectric & 262 & 500 \\
Urban solid wastes & 30355 & 42494 \\
\hline Total electricity & & \\
\hline
\end{tabular}

generation was mostly driven by expectations of substantial future increase in power demand in the country, as economic growth of the Spanish economy seemed robust in the period 2000-2007. Moreover, investment in gas-fuelled plants was perceived as a low risk investment due to their relatively low investment costs, shorter construction periods, and lower carbon risk as compared to coal plants. CCGTs were the main option of utilities to respond to the increasing electricity demand, in a context of cheap financing. These plants were less risky, easy, fast, and relatively cheap to be built compared to other alternatives [11]. The Plan for Electricity and Gas Infrastructures 2002-2011 gave an undeniable backing for the investment in CCGTs. This plan envisaged the construction of $14.8 \mathrm{GW}$ of CCGTs, which was considered an "adequate" amount by the electricity sector association $[11,12]$. This target was increased to $30 \mathrm{GW}$ in 2005. It was an indicative target, that is, not binding neither for the state nor for the firms.

3.3.2. Renewable Energy Technologies. Two main planning documents for RES were the Renewable Energy Plans in 1999 [13] and 2005 [14]. Table 2 includes the objectives set in both documents for electricity from renewable energy sources (RES-E).

3.4. Easy Granting of Administrative Authorisations. The regions (or Autonomous Communities, AACC), which had competencies on the siting of electricity generation plants, were eager to grant permits to these plants, either because this allowed them to comply with the mandate that they should ensure their security of supply [7] or because this was regarded as a source of jobs for the region.

Regarding RES, there was no centralised authorisation procedure for RES plants in Spain. Administrative permits were easily and quickly granted by the AACC, given the high level of perceived local benefits and the fact that the costs were shared by all electricity consumers nationally [15].

3.5. Macroeconomic Factors. Spain went under an economic boom in the late 1990s until 2007 and a deep crisis thereafter. Obviously, this economic cycle explains first the quick 
increase in electricity demand (triggering the aforementioned concern of the government about the possibility of blackouts) and a stagnant, eventually depressed, electricity demand since 2008. Both industrial and residential demand increased significantly, and the latter also triggered by the housing boom.

Another important, and associated, key factor contributing to the overinvestment in the Spanish power sector was the availability of large volumes of cheap debt. Until 2008, banks were eager to lend money at relatively low interest rates, which favoured (over)investments across economic sectors, markedly the construction sector, but also in new power generation capacity.

\section{What Are the Effects of Overcapacity?}

The large overcapacity present in the Spanish power system has tangible economic consequences at system level (societal perspective) and for power market actors (both conventional and renewable generators).

At the system level, overcapacity results in the underutilisation of assets, which in turn results in a suboptimal allocation of economic resources.

Market actors also suffer the consequences of overinvestment. As a result of the substantial increase in generation capacity available, and the stagnation of (peak) power demand levels, natural gas-fuelled plants have seen a radical reduction in their utilisation factor over the last few years. In addition to the increased competition from other conventional generators, the substantial growth in renewable generation, which is granted priority dispatch in EU power markets, has further reduced the number of hours in which gas plants operate. Consequently, during the last years, the capacity factors for most CCGT plants have been well below those expected when investment decisions were made. Electricity generation from CCGTs has been reduced from 50 TWh in 2011 to 23 TWh in 2013 (see [12]). The reduction in nuclear, fuel oil, and coal has not been so dramatic. After the Royal Decree 134/2010, which supported national coal consumption, the situation was made even worse for CCGTs plants (Real Decreto 134/2010, de 12 de febrero, por el que se establece el procedimiento de resolución de restricciones por garantía de suministro y se modifica el Real Decreto 2019/1997, de 26 de diciembre, por el que se organiza y regula el mercado de producción de energía eléctrica). Given this situation, there is no expectation of investments in new capacity in the short term, except for renewable technologies and for fuel oil power plants substitution in the islands [16].

Besides the reduced number of hours of operation, overcapacity also puts downward pressure on wholesale market prices, further decreasing the business case for gas plants. There is a large amount of evidence showing this merit order effect in Spain (see, e.g., [17-19]).

The main consequence for conventional electric utilities has been stranded assets and a considerable reduction in their cash flows. Furthermore, investments on new generation capacity were highly leveraged. As a result, the Spanish firms (whether conventional or renewable) are among the most indebted in the EU, with debt as high as four times their EBITDA (Earnings Before Interest, Taxes, Depreciation, and Amortization) [7].

Similarly, for renewable generators, overcapacity results in two main negative effects: firstly, the downward pressure on wholesale power prices, while positive for electricity consumers, results in an increased competiveness gap (difference between the RES generation costs and the revenues obtained from the market), increasing the need for support per unit of energy generated; secondly, overcapacity hinders further penetration of renewables in the system since, under such conditions, it is difficult to justify politically the provision of economic support for new RES plants, which are not needed from a strict "security of supply" point of view.

\section{What Are the Policy Options to Address the Overcapacity Issue and Open More Space for Further Renewable Deployment?}

Given the dimensions of the problem described above, it seems very likely that its effects will last long and that the adjustments required to stabilise the situation will be deep.

Spain is equipped with a relatively young power plant fleet. During the last ten years, massive investments have been made in new natural gas-fired power plants. Almost no new coal power plants and also no new nuclear power plants have been brought online in Spain for at least twenty years.

According to Fichtner et al. [20], the retirement rate in the $2010-2020$ period is about $24 \%$. The installed capacity in 2010 amounted to $98000 \mathrm{MW}$, whereas the expected retirement in the period would be $23834 \mathrm{MW}$.

While it can be expected that the recovery of the Spanish economy will result in increasing levels of demand which will contribute to the correction of this issue in the long term, short-term (RES) energy policy decisions need to carefully take into account the current situation.

5.1. Measures Adopted So Far. Energy policy decisions in Spain seem indeed to have been influenced by this issue in the last few years.

The abrupt cancellation of economic support for all new RES plants in early 2012, aimed at containing increasing RES support costs, resulted also in an effective halt in new RES deployments in the country. Although a new RES support scheme is in place since 2014, this has not triggered a recovery in investments in the renewable sector so far.

In the Energy Reform of 2013, the Spanish Government tabled a regulatory framework for the "hibernation" (temporary closing) of combined cycle gas plants. Although the regulation has not been approved so far, the Spanish Government is considering the temporary closing of $6 \mathrm{GW}$ of CCGTs in its infrastructure plan for the period 2015-2020 [21].

The Spanish Government has also been pushing actively in recent years for an expansion of the interconnection capacity with France, which could possibly result in increased electricity exports to northern EU countries, partially mitigating the effects of the Spanish overcapacity problem. 
While these measures may help mitigate the effects of overcapacity in the short term, a long-term sustainable solution to the issue, enabling further penetration of renewable generation in line with 2030 RES objectives, would require a broader list of policy measures.

5.2. Alternative Policy Measures. Overcapacity is a serious short-term problem; however, the possible solutions to this problem may also open opportunities to accelerate a broader long-term transition to a low-carbon energy system. The excess generation capacity can be corrected by adopting measures both on the demand and on the supply side.

On the demand side, setting up policy incentives to increase domestic demand of electricity seems at first incompatible with EU energy efficiency and climate strategy and commitments. However, these policies could be justified if they offset primary energy consumption in other sectors. In this sense, the overcapacity in the electricity system may be an opportunity to accelerate the electrification of the heat and transport sectors, which is arguably a main trend for the decarbonisation of the whole economy [1]. Policy measures to move in this direction in the transport sector could include incentives for electric vehicles or "electricityto-fuel" solutions. Similarly, in the heat sector, incentives to increase the penetration of efficient heat pumps could result in increased demand in the power sector offset by larger consumption reductions in the heat sector.

The supply side can also contribute to the correction. The excess generation capacity built in Spain has a positive side which is that the most polluting plants remaining in the system are no longer critical to guarantee security of supply. The Spanish Government could take this opportunity to require a gradual coal phase-out in the medium term, for example, deincentivise the continuation of the most polluting plants, for example, by establishing stricter environmental standards for combustion plants and removing existing subsidies for the consumption of domestic coal.

The Spanish Government could also reconsider the policy effectiveness and economic efficiency of existing capacity payments for dispatchable generation plants. The rationale for these payments is to incentivise investment in new plants when there are concerns about generation adequacy. Spain has currently the opposite problem. Capacity payments are hardly justified in these conditions except for strategic plants, for example, those placed in specific network hubs with an additional need for dispatchable capacity.

The goal set up in the Energy Union Package of a minimum interconnection target set for electricity at $10 \%$ of installed electricity production capacity of the Member States by 2020 and $15 \%$ by 2030 could certainly provide an opportunity for Spain to deliver electricity to other countries, such as Germany or Italy. In fact, interviews carried out for this project show that the improvements in the interconnection capacity with other countries are regarded as a main option to mitigate the overcapacity problem (see below).

5.3. Measures to Avoid New Overcapacities in the Future. Given the relatively low capacity factor of RES and the need for backup capacity from conventional electricity sources, it can be argued that electricity systems with a large penetration of RES are inherently more capacity-intensive than others in order to produce a given amount of electricity and ensure the security of supply at all times during the day (baseload and peak-load).

Even if systems with high RES penetration may require somewhat larger shares of standby capacity, it is important to incorporate the lessons learned about the past conditions that created the current overcapacity problem into future longterm energy policy decisions.

In order to avoid building new unhealthy overcapacities in the future, developments on the conventional generation side need to be carefully coordinated with national renewable energy deployment objectives. Actual levels of deployment, both on the conventional and on the renewable side, need to be frequently monitored. It is critical that national authorities, in charge of long-term energy planning, and local and regional authorities, usually in charge of permitting procedures, coordinate very closely.

\section{The Results of the Interviews on Stakeholders}

6.1. Aim and Methodology. A survey among stakeholders was launched on October-November 2015. Its aim was to know the opinion of these stakeholders on the causes and consequences of overcapacity of electricity generation as well as the policies to address this problem. An open list of possible items in each category was provided to the interviewees, who were also free to mention other items. The Interview Guide (List of Items) is provided.

Causes

(1) Risk of black-outs at the end of the 90s.

(2) Problems in planning (wrong projections of electricity demand).

(3) Cheap and easy financing.

(4) The economic boom led to a considerable growth in demand.

(5) Positive signals by the government for investments in renewable energy.

(6) Positive signals by the government for investments in CCGTs.

(7) Easy granting of administrative permits by the regions (AACC).

(8) Overcapacity is an inherent problem for electricity systems with a high RES penetration.

\section{Consequences}

(1) Overcapacity leads to an suboptimal allocation of economic resources.

(2) It is rather a distributive issue: the losers are the investors in CCGTs. 
TABLE 3: Responses of the interviewees on the causes of overcapacity.

\begin{tabular}{lcccc}
\hline Interviewee & \multicolumn{2}{c}{ Most relevant } & \multicolumn{2}{c}{ Least relevant } \\
& First & Second & Second least-relevant & Least relevant \\
\hline Utility A & 4 & 2 & 1 & 1 \\
Regulator A & 2 & 5 & 5 & 7 \\
Utility B & 2 & 6 & 1 & 8 \\
Regulator B & 2 & 4 & 2 & 8 \\
Regulator C & 3 & 4 & 6 & 8 \\
Regulator D & 5 & 4 & - & 7 \\
Expert A & 2 & 6 & - & 8 \\
Expert B & 2 & 1 & 8 & 7 \\
Expert C & - & - & 6 & 7 \\
Renewable energy association & 2 & 4 & & 7 \\
Utility C & 2 & 4 & & 7 \\
\hline
\end{tabular}

Note: (1) risk of blackouts at the end of the 90s, (2) problems in planning (wrong projections of electricity demand), (3) cheap and easy financing, (4) the economic boom led to a considerable growth in demand, (5) positive signals by the government for investments in renewable energy, (6) positive signals by the government for investments in CCGTs, (7) easy granting of administrative permits by the regions (AACC), and (8) overcapacity is an inherent problem for electricity systems with a high RES penetration.

(3) It is rather a distributive issue: the losers are the investors in renewable energy technologies.

(4) It is rather a long-term problem in the context of a transition towards a new energy model: overcapacity is a very important obstacle for future investments in renewable energy.

Policies

Already Adopted. Which of those measures not yet adopted are more effective to mitigate the problem in the short-term?

(1) The moratorium on renewable electricity generation investments adopted in 2012.

(2) The hibernation of CCGTs.

(3) The improvement in the interconnection capacity with other countries.

Not Yet Adopted. Which of those measures already adopted are more effective to mitigate the problem in the long-term?

(1) Incentives for the electrification of the transport sector and/or heat in buildings (efficient heat pumps).

(2) Opportunity to discourage the operation of the most polluting electricity generation plants.

(3) Termination of capacity payments for dispatchable generation plants.

(4) A better long-term energy planning.

Interviewees were asked to order those items in descending order according to their relevance, that is, from more important (1) to least important.

An e-mail interview with structured responses was sent to different types of stakeholders (see List of Stakeholders). These included energy experts, energy regulators, and the renewable energy associations. 15 people were contacted, with no aim of representativeness. 11 accepted to respond to the interview. The following list provides a list of the interviewees. Three interviews belong or have belonged to an electric utility, four have been or are energy regulators, three are energy experts, and one comes from a renewable energy association. Their anonymity was guaranteed and, thus, their names cannot be provided.

List of Stakeholders includes

electric utility A,

former regional government official in charge of industry and energy matters,

electric utility B,

energy regulator (currently),

energy regulator (currently),

energy regulator (formerly),

energy expert,

energy expert,

energy expert,

formerly at electric utility C,

renewable energy association.

6.2. Main Results. In this section, the main results of the empirical analysis are provided, distinguishing between the causes and consequences of overcapacity as well the policies to mitigate this problem.

6.2.1. Causes. Table 3 provides a summary of the responses of the interviewees. The list of interviewees is included in the rows. The answers are grouped in two categories depending on the relevance attached to the different items (the two most and least relevant items). The numbers in the cell refer to the specific item (i.e., see "Interview Guide (List of Items)"). One expert did not answer the part of the interview on the 
TABLE 4: Responses of the interviewees on the consequences of overcapacity.

\begin{tabular}{lcccc}
\hline Interviewee & \multicolumn{2}{c}{ Most relevant } & \multicolumn{2}{c}{ Least relevant } \\
& First & Second & Second least relevant & Least relevant \\
\hline Utility A & 1 & 2 & 3 & 4 \\
Regulator A & 1 & 4 & 3 & 2 \\
Utility B & 1 & 4 & 4 & 2 \\
Regulator B & 1 & 2 & 3 & 3 \\
Regulator C & 1 & 2 & 2 & 3 \\
Regulator D & 1 & 4 & 3 & 3 \\
Expert A & 1 & 2 & 3 & 2 \\
Expert B & 1 & 4 & 2 & 3 \\
Expert C & 1 & 4 & 3 & 2 \\
Renewable energy association & 1 & 4 & 4 & 3 \\
Utility C & 1 & 4 & 2 & 3 \\
\hline
\end{tabular}

Note: (1) it leads to a suboptimal allocation of economic resources, (2) it is rather a distributive issue: the losers are the investors in CCGTs, (3) it is rather a distributive issue: the losers are the investors in renewable energy technologies, and (4) it is rather a long-term problem in the context of a transition towards a new energy model: overcapacity is a very important obstacle for future investments in renewable energy.

causes and another did not provide his/her opinion on the least relevant causes of overcapacity.

Regarding the causes of overcapacity in Spain, an overwhelming majority of interviewees considered that lack of planning could be blamed for this problem. After that, the economic boom leading to a considerable increase in demand was pointed out as a main factor behind this problem. In contrast, the easy granting of administrative permits by the regional governments and overcapacity being an inherent problem in systems with a high RES penetration are deemed the least relevant causes of overcapacity. No noticeable differences across different types of actors can be discerned.

6.2.2. Consequences. Regarding the consequences (Table 4), the eleven interviewees unanimously indicated that overcapacity would lead to a suboptimal allocation of economic resources. This response was followed in importance by the answer "it was rather a problem for the future in the context of the transition towards a new energy model. Overcapacity is a very important obstacle for future investments in renewables." Therefore, overcapacity was clearly identified as a highly relevant barrier for further investments in renewable energy technologies. The interviewees were much less concerned about the distributive consequences of overcapacity in terms of losses for investors in CCGTs and, even more so, for those who invested in RES. Again, differences in the responses across actor types cannot be identified.

6.2.3. Policies. Finally, regarding the policies to address this problem, two types of policies were differentiated, depending on their short-term (effectiveness of already implemented measures) or long-term scope (what to do in order to mitigate the problem in the long-term).

Regarding the short-term policies (see Table 5), most interviews (6) considered that the improvement in the interconnection capacity with other countries could mitigate the problem. This was followed by "hibernation of CCGT plants" could mitigate the problem (3 interviewees) and
TABLE 5: Responses of the interviewees on the short-term policies to mitigate overcapacity.

\begin{tabular}{lcc}
\hline Interviewee & Most relevant & Least relevant \\
\hline Utility A & 1 & 3 \\
Regulator A & 3 & 1 \\
Utility B & 2 & 1 \\
Regulator B & 3 & 1 \\
Regulator C & 1 & 3 \\
Regulator D & 3 & 1 \\
Expert A & 3 & - \\
Expert B & 2 & 1 \\
Expert C & 2 & - \\
Renewable energy association & 3 & 1 \\
Utility C & 3 & 1
\end{tabular}

Note: (1) the moratorium to renewable electricity generation investments adopted in 2012, (2) the hibernation of CCGTs, and (3) the improvement in the interconnection capacity with other countries.

"the moratorium to RES electricity generation could mitigate this problem" (2 interviewees). This last question was also considered to be the least relevant by an overwhelming majority of interviewees (7).

Regarding what to do to solve the problem in the long-term (Table 6), five interviewees argue that this is an opportunity to discourage the operation of more polluting power plants. Four claim that a better long-term energy planning could have improved this problem in the first place. Providing incentives for electrification of the transport and heat sectors and removing capacity payments for dispatchable power plants are not regarded as a solution to the problem. Differences in the responses across actor types for both shortterm and long-term policies cannot be identified.

\section{Conclusions}

An excessive electricity generation capacity has been accumulated in Spain in the last decade. This overcapacity 
TABLE 6: Responses of the interviewees on the long-term policies to mitigate overcapacity.

\begin{tabular}{lcccc}
\hline \multirow{2}{*}{ Interviewee } & \multicolumn{2}{c}{ Most relevant } & \multicolumn{2}{c}{ Least relevant } \\
& First & Second & Before last & Last \\
\hline Utility A & 4 & 1 & 2 & 3 \\
Regulator A & 2 & 1 & 4 & 3 \\
Utility B & 2 & 1 & 4 & 3 \\
Regulator B & 4 & 2 & 1 & 3 \\
Regulator C & 1 & 2 & 4 & 3 \\
Regulator D & 2 & 1 & 4 & 3 \\
Expert A & 4 & - & - & - \\
Expert B & 2 & 3 & 4 & 1 \\
Expert C & 4 & 1 & 2 & 3 \\
Renewable energy association & 3 & 2 & 1 & 4 \\
Utility C & 2 & 3 & 1 & 4 \\
\hline
\end{tabular}

Note: (1) incentives for the electrification of the transport sector and/or heat in buildings (efficient heat pumps), (2) opportunity to discourage the operation of the most polluting electricity generation plants, (3) termination of capacity payments for dispatchable generation plants, and (4) a better energy long-term planning.

problem, caused by several factors, has several detrimental consequences and, most importantly, it can be considered a barrier for the future deployment of RES. Several policy alternatives have been proposed to deal with this problem, either in a short-term or in a long-term horizon. This paper has analysed those causes and consequences, using official data as well as interviews to relevant stakeholders. It has also tried to identify the opinions of different stakeholders with respect to policies which may mitigate the problem in the short or the long terms.

Overcapacity is clearly an economic problem in terms of the efficiency of the allocated resources (i.e., short term). But it is also a problem in a long-term horizon in so far as it could represent a barrier to an energy transition based on a large amount of RES.

A main lesson of this study for other countries is that energy planning should play a critical role to mitigate the possibility that a problem of overcapacity emerges. In particular, such planning should appropriately adjust to changes in the economic cycle. Several options to mitigate the overcapacity problem have been put forward in Section 6. Although stakeholders have their own preferences, the different alternatives should not be regarded as mutually exclusive. Indeed, in such a complex problem, with also difficult solutions, a combination of different options can be recommended.

\section{Competing Interests}

The authors declare that there are no competing interests regarding the publication of this paper.

\section{Acknowledgments}

This paper builds on the analysis conducted in the Intelligent Energy Europe (IEE) project "Dialogue on a RES policy framework for 2030 (Towards2030-dialogue)." The TOWARDS2030-dialogue project is an initiative that could be established thanks to the financial and intellectual support offered by the Intelligent Energy Europe (IEE) Programme of the European Commission, operated by the Executive Agency for Small and Medium Enterprises. For more details on the project, see http://towards2030.eu/.

\section{References}

[1] International Energy Agency, Energy Technology Perspectives, International Energy Agency, Paris, France, 2014.

[2] P. Del Río, "Analysing future trends of renewable electricity in the EU in a low-carbon context," Renewable and Sustainable Energy Reviews, vol. 15, no. 5, pp. 2520-2533, 2011.

[3] REE, Informe del Sistema Eléctrico Espanol 2014, 2014, http://www.ree.es/es/publicaciones/sistema-electrico-espanol/ informe-anual/informe-del-sistema-electrico-espanol-2013.

[4] 50Hertz, Amprion, Tennet, and TransnetBW, Bericht der deutschen UÜbertragungsnetzbetreiber zur Leistungsbilanz 2014 nac h EnWG $\$ 12$ Abs. 4 und 5, 2014, http://www.bmwi.de/BMWi/ Redaktion/PDF/J-L/leistungsbilanzbericht-2014,property $=$ pdf, bereich $=$ bmwi2012, sprache $=$ de, $r w b=$ true.pdf.

[5] Ministry of Industry (MINETUR), The reform of the Spanish power system: towards financial stability and regulatory certainty, 2013, http://www.thespanisheconomy.com/stfls/tse/ ficheros/2013/agosto/Power_System_Reform.pdf.

[6] CNE, Informe marco sobre la demanda de energía eléctrica y gas natural, y su cobertura, 2001.

[7] D. Lacallle, Por qué sube la luz si España tiene un $40 \%$ de sobre capacidad de producción? Inversión \& Finanzas, 2014, http://www.finanzas.com/noticias/economia/20141114/lacallesube-espana-tiene-2804357.html.

[8] J. González, España tiene 107.615 MW de potencia eléctrica y sólo necesita la mitad ABC, October 2013, http://www.abc.es/ economia/20131021/abci-espana-tiene-potencia-electrica201310211202.html.

[9] REE, Informe del Sistema Eléctrico Espanol 2012, 2013, http://www.ree.es/es/publicaciones/sistema-electrico-espanol/ informe-anual/informe-del-sistema-electrico-espanol-2012.

[10] REE, Informe del Sistema Eléctrico Espanol 2014, 2015, http:// www.ree.es/es/publicaciones/sistema-electrico-espanol/informeanual/informe-del-sistema-electrico-espanol-2014.

[11] A. Bolaños, "Mucho gas para tan poca luz," El País, 2013, http:// sociedad.elpais.com/sociedad/2013/12/26/actualidad/1388082770_ 720869.html.

[12] UNESA, Informe Eléctrico Memoria de Actividades Memoria Estadística, 2013.

[13] IDAE, Plan for the Promotion of Renewable Energy (PFER), Instituto Para la Diversificación y el Ahorro de la Energía, Spanish Ministry of Science and Technology, 1999.

[14] IDAE, Renewable Energy Plan 2005-2010, Instituto para la Diversificación y el Ahorro de la Energía, Spanish Ministry of Industry, Tourism and Trade, 2005.

[15] P. Del Río, A. Calvo, and G. Iglesias, "Policies and design elements for the repowering of wind farms: a qualitative analysis of different options," Energy Policy, vol. 39, no. 4, pp. 1897-1908, 2011.

[16] Store Project, Facilitating energy storage to allow high penetration of intermittent renewable energy. D5.2-SPAIN. Overview 
of current status and future development scenarios of the electricity system, and assessment of the energy storage needs, 2014, http://www.store-project.eu.

[17] G. Sáenz de Miera, P. del Río González, and I. Vizcaíno, "Analysing the impact of renewable electricity support schemes on power prices: the case of wind electricity in Spain," Energy Policy, vol. 36, no. 9, pp. 3345-3359, 2008.

[18] L. Gelabert, X. Labandeira, and P. Linares, "An ex-post analysis of the effect of renewables and cogeneration on Spanish electricity prices," Energy Economics, vol. 33, no. 1, pp. S59-S65, 2011.

[19] M. T. Costa-Campi and E. Trujillo-Baute, "Retail price effects of feed-in tariff regulation," Energy Economics, vol. 51, pp. 157-165, 2015.

[20] Fichtner, "Study on incentives to build power generation capacities outside the EU for electricity supply of the EU," Final Report, 2012.

[21] MINETUR, Planificación Energética: Plan de Desarrollo de la Red de Transporte de Energía Eléctrica, Primera Propuesta, 2014, http://www.minetur.gob.es. 

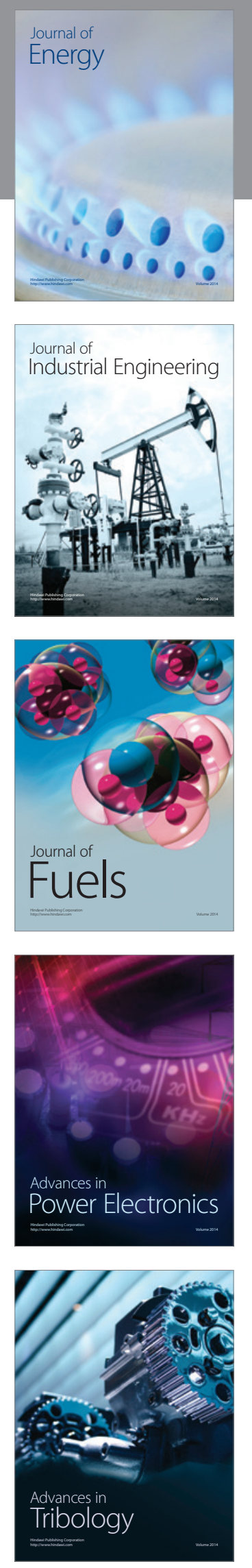
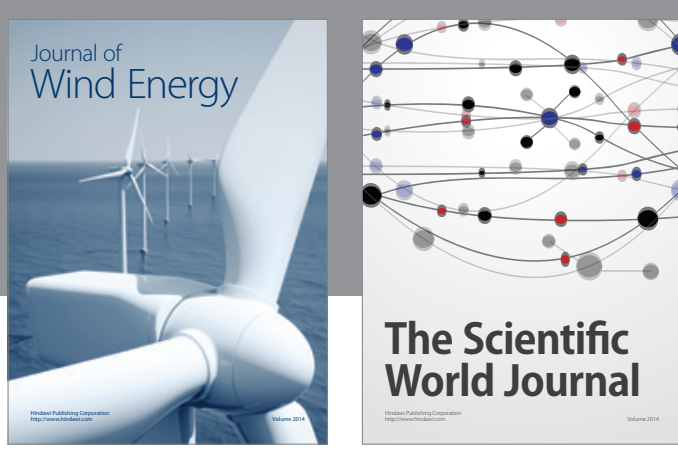

The Scientific World Journal
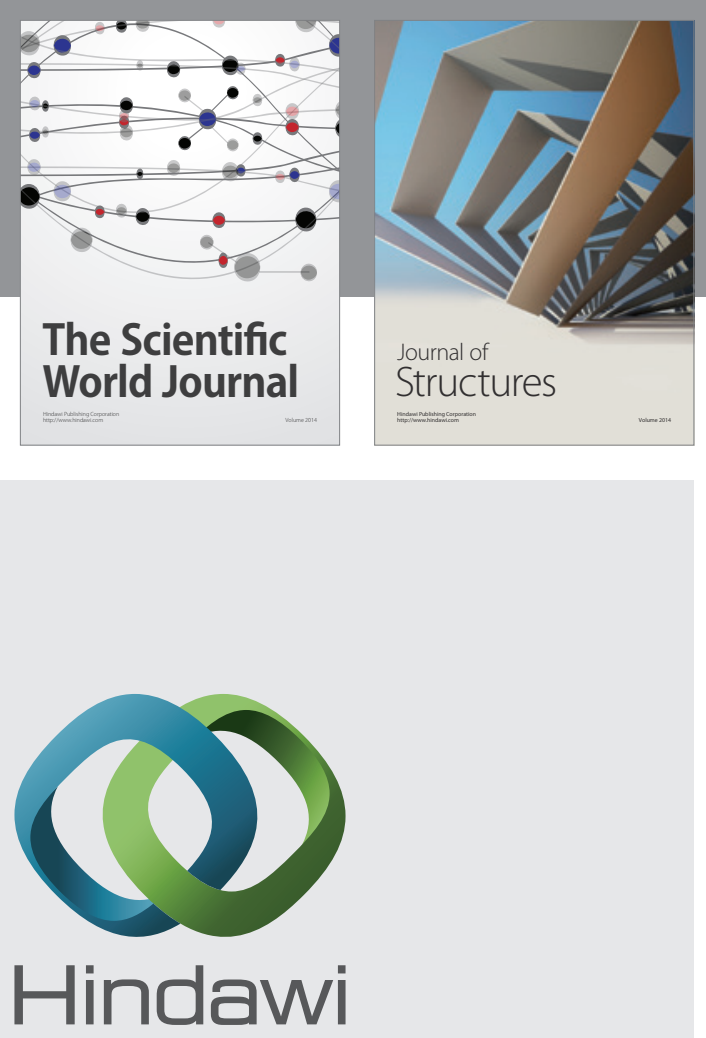

Submit your manuscripts at

http://www.hindawi.com
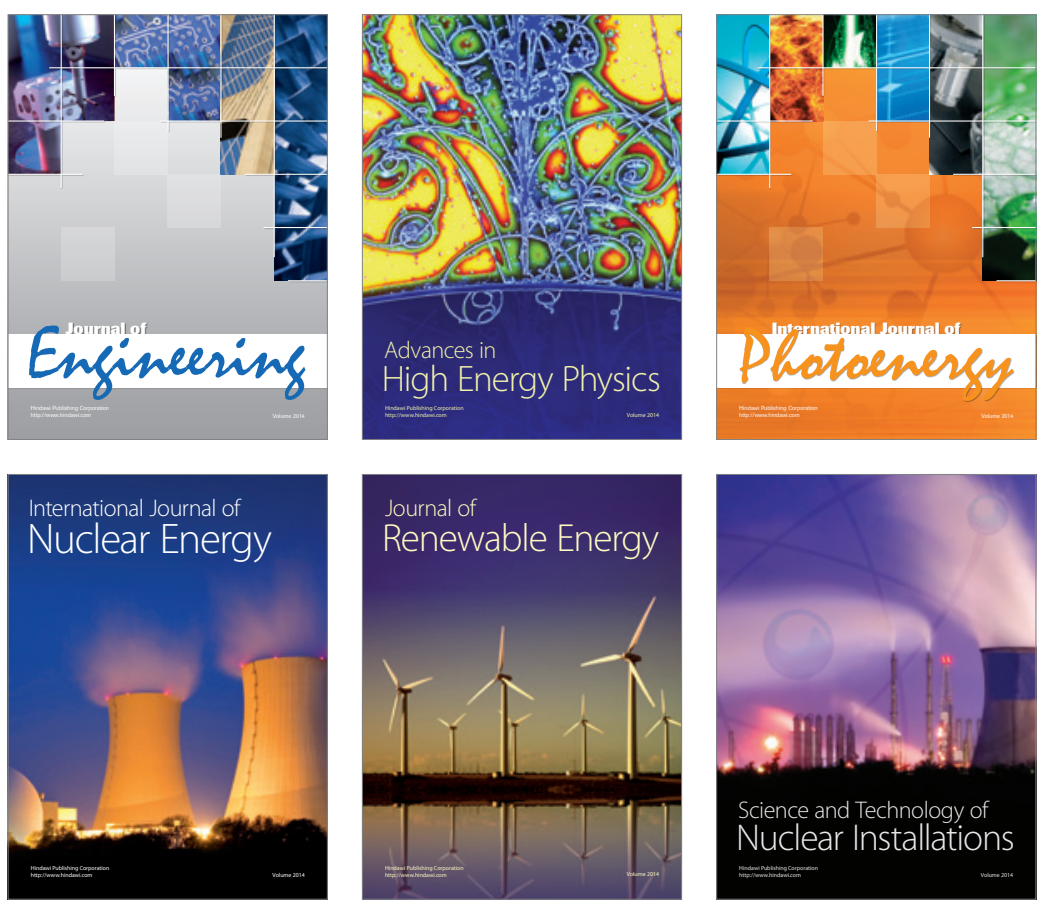
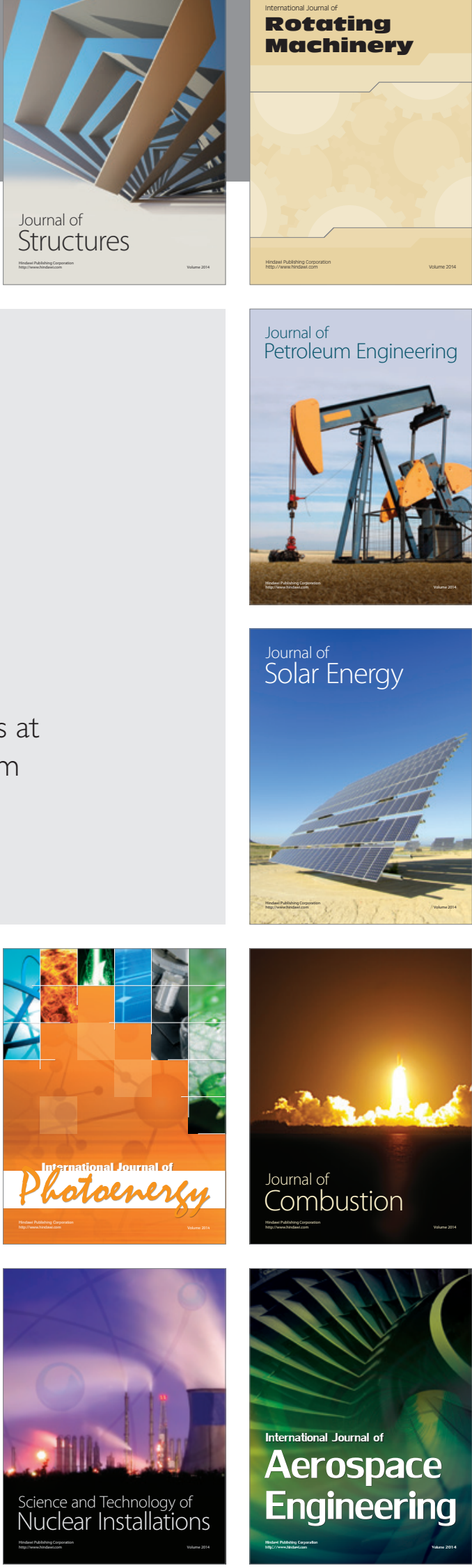